\title{
Pengalaman Komunikasi Penyandang Kanker Serviks dalam Pencarian Informasi Pengobatan di Jawa Barat
}

\author{
Purwanti Hadisiwi ${ }^{1}$ dan Hadi Suprapto Arifin ${ }^{2}$ \\ ${ }^{1,2}$ Universitas Padjadjaran
}

\begin{abstract}
ABSTRAK
Banyak penyandang kanker serviks yang terdiagnosis awal sudah berada pada stadium lanjut. Hal ini diantaranya disebabkan oleh perbedaan aksesnya terhadap informasi kesehatan serta tingkat pemahaman yang berbeda terhadap informasi yang diterimanya. Penelitian ini bertujuan untuk mengetahui pengalaman komunikasi penyandang kanker serviks di Jawa Barat, pola pencarian informasi kesehatan dan jenis informasi kesehatan yang diperlukan penyandang kanker serviks. Metode yang digunakan dalam penelitian adalah metode kualitatif dengan pendekatan fenomenologis. Melalui wawancara mendalam terhadap delapan penyandang kanker serviks yang berasal dari Bandung, Bekasi, Karawang, Indramayu, Cirebon dan Pangandaran diperoleh pemahaman bahwa, penyandang kanker serviks yang berasal dari strata sosial ekonomi rendah cenderung merasa terstigma sehingga menghambat aksesnya terhadap informasi dan berimplikasi pada kondisi stadium kanker serviks yang tinggi; mereka yang berasal dari strata sosial ekonomi rendah mendapatkan informasi kesehatan dari teman/kerabat dan dokter, sedangkan yang berasal dari strata yang lebih tinggi selain mendapatkan informasi kesehatan dari dokter, mereka juga mendapatkan informasi dari teman/komunitas dan media massa; mereka memerlukan informasi tentang penyakitnya, pengobatan dan jenis tindakan yang harus dijalani, nutrisi serta gaya hidup yang dapat memperpanjang harapan hidupnya. Diperlukan informasi tentang kanker serviks yang mudah diakses dan mudah dipahami disertai dengan pemberdayaan kader kesehatan yang dapat memberikan pendampingan kepada perempuan yang memiliki gejala awal kanker serviks.
\end{abstract}

Kata-kata Kunci: Fenomenologi; kanker serviks; pencarian informasi; pengalaman komunikasi; pengobatan

\section{Communication Experience of Cervical Cancer Survivors in Search of Medical Information in West Java}

\begin{abstract}
There were many of cervical cancer survivors were early diagnosed at an advanced stage. This was partly due to their differences in access to health information as well as differences in understand the information. This study aimed to determine the profile of cervical cancer survivors, health information search patterns and health information type needed by cervical cancer survivor in West Java. The method used in this research was qualitative method with phenomenological approach. Through in-depth interviews of eight cervical cancer survivors originating from Bandung, Bekasi, Karawang, Indramayu, Cirebon and Pangandaran, it was found that cervical cancer survivor from low socioeconomic status tended to feel stigmatized and hampered their access to information and its implication of high stage of cervical cancer; those from lowsocioeconomic strata obtain health information from friends / relatives and doctors, while those from higher status obtain health information not only from doctors, but also friends / communities and mass media; they need information about their health condition, treatment and medication, nutrion and lifestyle that can extend their life expectancy. It was required some information about cervical cancer that was accessible and easy to understand accompanied by the empowerment of health cadres that can provide assistance to women who have early symptoms of cervical cancer.
\end{abstract}

Keywords: Cervical cancer; communication experience; information search; medication; phenomenology

Korespondensi: Dr. Purwanti Hadisiwi, M.Exed, Program Studi Ilmu Komunikasi Fakultas Ilmu Komunikasi, Universitas Padjadjaran. Jalan Raya Bandung-Sumedang KM. 21 Jatinangor 45363. Email: purwanti@ unpad.ac.id 


\section{PENDAHULUAN}

Di sebuah rumah singgah kanker di kota Bandung, beberapa perempuan penyandang kanker serviks yang berasal dari daerah di luar kota Bandung sedang berbaring, atau melakukan kegiatan ringan lainnya. Mereka berada di rumah singgah kanker karena sedang melakukan pengobatan atau menjalani rangkaian tindakan pengobatan di RSHS. Mereka berasal dari Karawang, Bekasi, Cirebon dan Indramayu yang tidak memiliki sanak keluarga di kota Bandung. Dengan kondisi ekonomi yang tidak memungkinkannya untuk tinggal di penginapan, mengingat proses pengobatan yang memerlukan waktu lama, mereka pernah tinggal di bawah tangga rumah sakit, di kantor satpam dan bahkan di emperan rumah sakit. Kondisi mereka sangat memprihatinkan karena selain harus menginap di tempat yang tidak layak (sebelum di rumah singgah), mereka juga sudah pada stadium IIB dan IIIB. Stadium yang sudah relatif tinggi ini disebabkan terlambatnya mereka mengetahui informasi tentang gejala awal kanker serviks atau keengganannya memeriksakan diri karena menyangkut masalah pada organ intimnya. Dengan pendidikan yang rata-rata $\mathrm{SD}$ dan pekerjaan sebagai keliling, nelayan dan petani, mereka tidak mengetahui bagaimana mendapatkan informasi terkait gejala penyakit yang dialaminya sejak awal terjadi. Kanker serviks banyak dijumpai pada golongan sosial ekonomi rendah yang berkaitan dengan gizi dan imunitas, pada sosial ekonomi rendah umumnya kualitas dan kuantitas makanan kurang hal ini memengaruhi imunitas tubuh (Nuranna, 2008).

Sementara itu penyandang kanker serviks yang berpendidikan S1 dan tinggal di kota Bandung, memiliki pengalaman yang berbeda. Dengan program Keluarga Berencana yang diikutinya, mereka secara rutin memeriksakan diri ke dokter sehingga dapat diketahui sejak awal gejala kanker serviks yang dialaminya. Informasi yang diperolehnya dari dokter kemudian dikonfirmasikannya ke dokter lainnya, disertai dengan tambahan informasi dari berbagai sumber. Pengalaman yang berbeda ini bisa jadi disebabkan oleh tingkat pendidikan yang berbeda. Berdasarkan hasil penelitian tentang kanker payudara diketahui bahwa, terdapat hubungan yang positif antara tingkat pendidikan formal dengan tingkat pengetahuan wanita tentang kanker payudara. Semakin tinggi tingkat pendidikan maka semakin tinggi tingkat pengetahuannya (Widiawaty, 2011).

Literasi kesehatan yang erat kaitannya dengan tingkat pendidikan menjadi masalah besar di samping demografi karakteristik penyandang kanker serviks yang lainnya. Informasi tentang kanker serviks menjadi sangat penting diketahui oleh semua perempuan. Informasi yang dimulai dari gejala awal terindikasinya kanker serviks, pengobatan dan tindakan yang harus dijalani, pencegahan untuk terhindar dari kanker serviks serta Kanker Serviks merupakan penyakit kanker pembunuh wanita kedua setelah kanker payudara. Menurut data World Health Organization (WHO) setiap hari ada dua perempuan yang meninggal karena penyakit ini dan $83 \%$ penyakit kanker serviks berada di Negara berkembang. Di Indonesia kanker serviks ditemukan pada 40-45 perempuan Indonesia setiap harinya. Menurut Yayasan Kanker Indonesia, kanker serviks menyumbang angka kematian paling banyak dan 52 juta perempuan Indonesia berisiko terkena kanker serviks.

Angka kejadian kanker serviks sangat bervariasi di seluruh dunia. Meskipun progam pap smear sudah dicanangkan namun sekitar 20 persen kejadian kanker serviks tidak terdeteksi, terutama adenokarsinoma serviks, yang lebih sulit untuk dideteksi melalui metode - metode pap smear yang telah ada. Banyak faktor yang dapat memengaruhi terjadinya kanker serviks di antaranya adalah kawin di usia muda, pendidikan, pekerjaan dan seringnya melahirkan (FKUI Jakarta, 2000 dalam Kumpulan Karya Tulis Kebidanan, 2011).

Jawa Barat merupakan salah satu provinsi dengan angka kanker serviks yang tinggi. Saat ini, kanker masih dianggap sebagai hal yang menakutkan. Bagi orang yang divonis kanker, mereka akan berada pada situasi disonansi atau situasi ketidakpastian. Sebagian dari mereka terpukul dan ketakutan. Berbagai tindakan kemudian dilakukan sebagai upaya pengobatan. Jenis pengobatan yang dipilih bergantung kepada informasi yang diperoleh. Informasi kesehatan akan membantu pasien untuk mengatasi masalah kesehatannya, berkomunikasi dengan penyedia layanan kesehatan dan membuat keputusan untuk pengobatan (Freimuth, et al, 1989; Marshall, 1993). Senada dengan itu, Rutten menyebutkan bahwa informasi yang baik bagi 
pasien kanker dapat membantu mereka dalam menghadapi diagnosis, pengobatan, bahkan dapat meningkatkan ketahanan hidup dan kualitas hidup (Loo, 2007).

Di Jawa Barat, saat ini jumlah penderita kanker serviks menempati urutan kedua terbanyak di Indonesia. Rata-rata setiap tahun penderita kanker serviks yang datang ke Rumah Sakit Hasan Sadikin (RSHS) berjumlah 400 orang. Mayoritas dari daerah pantura Jabar. "75 persennya sudah mencapai stadium lanjut," kata ahli kandungan RSHS Prof. Dr. Herman Susanto pada bincang-bincang Pencegahan Kanker Serviks di UPT Kesehatan Unpad, Bandung.

Penelitian "Profil dan Pencarian Informasi Penyandang Kanker Serviks Dalam Upaya Pengobatan di Jawa Barat" ini beranjak dari konteks permasalahan sebagaimana digambarkan di atas. Meningkatnya angka penyandang kanker serviks menjadi permasalahan yang perlu diketahui secara lebih saksama. Siapa dan bagaimana kondisi penyandang kanker serviks di Jawa Barat serta bagaimana akses dan kemampuannya dalam memperoleh dan mengandalkan informasi kesehatan bagi penyembuhan penyakitnya menjadi hal yang menarik untuk diteliti lebih lanjut. Tujuan penelitian ini adalah untuk mengetahui profil penyandang kanker serviks, mengetahui pola pencarian informasi kesehatan penyandang kanker serviks dan mengetahui jenis informasi kesehatan yang dibutuhkan para penyandang kanker serviks di Jawa Barat.

\section{METODE PENELITIAN}

Pendekatan fenomenologi digunakan dalam penelitian ini untuk memperoleh gambaran yang sesungguhnya tentang keadaan, perasaan, pendapat dan harapan penyandang kanker serviks. Pemilihan pendekatan ini secara spesifik diharapkan dapat menguak pengalaman sadar para penyandang kanker serviks dalam mengonstruksi dirinya yang mengalami sakit dan mencari informasi untuk pengobatannya.

Pengumpulan data dilakukan melalui wawancara mendalam terhadap delapan penyandang kanker serviks yang berasal dari Kota Bandung, Bekasi, Karawang, Indramayu, Cirebon dan Pangandaran yang terpilih secara snowball karena minimnya data penyandang kanker serviks yang dapat diperoleh pada
Dinas terkait. Wawancara mendalam dilakukan secara semi-structured interview, dimana peneliti memiliki satu daftar pertanyaan atau topik spesifik yang akan dibahas yang sering disebut dengan "panduan wawancara" tetapi informan memiliki kebebasan untuk menjawab pertanyaan (Hadisiwi \& Mulyani, 2013).

Wawancara dilakukan di tempat yang berbeda seperti di Puskesmas, di Cafe, di Rumah Singgah kanker atau di rumah penyandang sepanjang Agustus - Oktober 2017. Selain data primer yang diperoleh dari wawancara mendalam dengan penyandang kanker serviks, data sekunder yang berupa penelitian terdahulu yang sejenis, konsep maupun teori yang diperoleh melalui kajian pustaka juga menjadi pendukung penelitian ini.

\section{HASIL DAN PEMBAHASAN}

Dalam 10 tahun terakhir, masyarakat yang menderita penyakit kanker di Jawa Barat bertambah banyak dua kali lipat. Saat ini, 21 dari 100.000 orang di Jabar diprediksi menderita penyakit kanker. Oleh karena itu, masyarakat diimbau menerapkan pola hidup bersih dan sehat, serta melakukan deteksi dini untuk mencegah perkembangan kanker. Hal tersebut disampaikan oleh Pembina Priangan Cancer Care (PrCC), Monty P Soemitro, dalam rangka memperingati Hari Kanker Sedunia, di area Town Center Kota Baru Parahyangan, Padalarang, Kabupaten Bandung Barat, Sabtu 4 Februari 2017.

Jawa Barat merupakan salah satu provinsi dengan angka kanker serviks yang tinggi. Saat ini, kanker masih dianggap sebagai hal yang menakutkan. Bagi orang yang divonis kanker, mereka akan berada pada situasi disonansi atau situasi ketidakpastian. Sebagian dari mereka terpukul dan ketakutan sebagian lagi mencoba berserah diri, pasrah dengan kondisi yang melingkupinya.

Penyebab dari kanker serviks yang sudah secara umum diketahui adalah wanita yang cenderung memiliki banyak partner berhubungan seksual atau suka bergonta-ganti pasangan seksual, menikah pada usia dini yakni dibawah 20 tahun, terlalu sering melahirkan dan yang belum banyak diketahui adalah kebiasaan merokok. Kandungan beracun dari rokok bisa memicu perkembangan sel kanker dan jika hal ini dikombinasikan dengan infeksi dari virus HPV, 
Tabel 1 Profil Subjek Penelitian Penyandang Kanker Serviks di Jawa Barat

\begin{tabular}{llllllll}
\hline No & Nama & Usia & Awal Sakit & Pendidikan & Pekerjaan & Stadium & Asal \\
\hline 1. & MV & 60 & 46 & S1 & Pensiunan & IB & Bandung \\
2. & AS & 47 & 35 & S1 & Ibu Rmh Tg & IA & Bandung \\
3. & DAR & 59 & 56 & SD & Petani & IIB & Indramayu \\
4. & ATK & 47 & 45 & SMP & Pedagang & IIB & Bekasi \\
5. & WAR & 41 & 40 & SD & Nelayan & IIIB & Cirebon \\
6. & YU & 49 & 47 & SD & Puskesmas & IIB & Pangandaran \\
7. & DR & 59 & 50 & SD & Ibu Rmh Tg & IIB & Karawang \\
8. & DH & 54 & 48 & S1 & Ibu Rmh Tg & IIIB & Bekasi \\
\hline
\end{tabular}

Sumber : Hasil penelitian, 2017

maka kanker serviks pun bisa dengan mudah muncul (Doktersehat, 2017). Kanker serviks dapat dicegah dengan melakukan program KB, Dengan mengikuti program Keluarga Berencana, kesehatan rahim kaum perempuan tetap terjaga dan perempuan terlindung dari infeksi virus HPV yang merupakan penyebab kanker serviks.

Berdasarkan data yang diperoleh dari penyandang kanker serviks yang menjadi subjek penelitian, diperoleh informasi bahwa usia awal didiagnosis kanker serviks adalah ketika berusia 35 tahun, namun ada juga yang didiagnosis awal sakit pada usia 59 tahun. Mereka berasal dari strata sosial ekonomi yang sangat beragam, dengan pengalaman sakit, interaksi dengan keluarga, lingkungan tempat tinggal interaksi dengan pihak medis yang juga beragam. Gambaran profil subjek penelitian penulis rangkum dalam tabel 1 .

Penyandang kanker serviks yang tersebar di Jawa Barat, penulis kategorikan berdasarkan fasilitas kesehatan sebagai penyandang kanker serviks dari Kota Bandung dan dari Luar Kota Bandung. Kategori ini dilakukan berkaitan dengan fasilitas kesehatan yang berbeda antara Kota Bandung sebagai ibu kota Provinsi Jawa Barat, dan luar kota Bandung. Kota Bandung sebagai ibu kota Provinsi memiliki Rumah Sakit Hasan Sadikin (RSHS) yang memiliki berbagai fasilitas kesehatan untuk berbagai macam penyakit. Dengan fasilitas yang dimilikinya, penyandang kanker serviks yang tinggal di kota Bandung relatif tidak memiliki hambatan yang berarti dibandingkan dengan penyandang kanker serviks yang berasal dari luar Bandung ketika memerlukan pelayanan pengobatan.

Data pada tabel 1 menunjukkan bahwa penyandang kanker yang berasal dari kota Bandung memiliki tingkat pendidikan yang jauh lebih tinggi dibandingkan dengan yang berasal dari luar kota Bandung. Penyandang kanker serviks dengan tingkat pendidikan yang tinggi menyadari pentingnya mengikuti program keluarga berencana. Hal ini terlihat dari jumlah anak yang mereka miliki yang masing-masing memiliki dua orang anak saja. Keduanya terdiagnosis menyandang kanker serviks ketika memeriksakan secara rutin penggunaan kontrasepsi program KB-nya yaitu IUD, seperti yang dinyatakan oleh AS yang terdiagnosis kanker serviks pada usia 35 tahun, "Saya pakai IUD, jadi kan periksa rutin 3 bulan sekali, itu dicari benang, lalu keluar darah... kata dokter ada benjolan segede kacang ijo kalo disentuh keluar darah..". Dari kejadian itu langsung dilakukan biopsi yang kemudian memunculkan hasil positif kanker serviks.

Kedua penyandang kanker serviks yang tidak saling mengenal ini memiliki keluarga yang sangat mendukung terhadap pengambilan keputusan dalam penanganan atau tindakan yang harus dijalani terkait penyakit yang harus dilakukan dengan cepat. Keluarga besarnya maupun lingkungan pergaulannya juga penuh perhatian dan memberi dukungan moril yang 
sangat positif. Banyak saudara dan sahabat yang menangis sambil mendoakan kesembuhannya. Penyandang kanker serviks yang berasal dari Bandung ini juga mendapatkan dukungan dari Bandung Cancer Society (BCS) dimana keduanya terlibat menjadi anggota tidak lama setelah menjalani tindakan operasi. Komunitas penyandang kanker menjadi sebuah wahana yang membuat para penyandang kanker merasa nyaman karena berbagai kesamaan yang mereka miliki terkait penyakit yang disandangnya. "Di dalam komunitas kita memperbanyak relasi, bisa saling menguatkan, ketemu dan sharing sama temen temen.." begitu penuturan AS. Penelitian sebelumnya menunjukkan bahwa

Exposure to a friend or family member with cancer might motivate those without a personal cancer history to seek information regarding treatment options, disease outcomes, available rehabilitation and support resources, or simply how to better cope with cancer and its treatment. Indeed, some cancer patients indicate their family members and friends are a primary source of medical information (Roach dkk, 2006).

Komunitas kanker adalah tempat mereka berbagi pengalaman sakit, pengalaman menjalani serangkaian tindakan untuk penyembuhan, mendapatkan informasi kesehatan langsung dari para ahli dan melakukan berbagai kegiatan sosial lainnya. Situasi yang berbeda dialami oleh penyandang kanker serviks yang bertempat tinggal di luar kota Bandung yang tingkat pendidikannya ratarata SD. ATK dari Bekasi mengalami gejala awal seperti menstruasi yang tak kunjung usai, namun tidak mau segera pergi ke dokter karena takut, seperti yang dituturkan, "Saya kan jualan bawa motor, haid terus gitu gak brenti keluar darah, tapi gak sakit, makan enak tidur enak, jadi gak dirasa. Gak mau priksa, ketauan dokter mah takut. Takut penyakitnya anu gitu ya.." ATK mengabaikan gejala awal kanker serviks, yaitu perdarahan yang abnormal, dan menangguhkan pergi ke dokter sehingga tingkat keparahan kanker serviksnya semakin tinggi.

Hingga saat ini di Jawa Barat baru ada tiga buah rumah sakit yang memiliki Pusat Pelayanan kanker secara terpadu atau terintegrasi, yaitu RS Hasan Sadikin Bandung, RS Santosa Bandung, serta RSUD Al Ihsan di Kabupaten Bandung. Keterbatasan fasilitas kesehatan untuk penyandang kanker ini menyebabkan penyandang kanker serviks yang berada di luar Bandung mengalami kesulitan mendapatkan tindakan pengobatan. Pengalaman ATK yang mengalami menstruasi berkepanjangan, ketika berobat ke Puskesmas di Karawang, hanya memperoleh respons, "Cuma faktor usia dan banyak pikiran..". ATK kemudian meminta rujukan dari Puskesmas untuk berobat ke RS Islam Karawang berkaitan dengan perdarahan yang terus menerus. Surat rujukan dari Puskesmas akhirnya diperoleh setelah ATK memintanya berkali-kali. ATK akhirnya "dikiret" sebanyak tiga kali di RS Islam Karawang tapi perdarahan masih saja terjadi. Akhirnya RS Karawang merujuk ATK ke RSHS di Bandung. Selama menjalani tindakan pengobatan di Bandung, ATK ditemani keluarganya hanya beberapa hari saja, tanpa kecukupan dana, ATK pernah tidur di sekitar IGD, di pos polisi, sampai kemudian ditawari tinggal di Rumah Singgah Kanker. Pengalaman serupa juga dialami oleh penyandang kanker dari Indramayu dan Cirebon. Sementara itu YY yang berdomisili di Pangandaran memilih dirawat di RSUD Margono di Purwokerto untuk mendapatkan tindakan kemoterapi.

Selain menghadapi kendala akses terhadap fasilitas kesehatan, penyandang kanker serviks juga berada pada situasi yang sangat tidak nyaman ketika harus berhadapan dengan lingkungan tetangga atau bahkan dengan lingkungan keluarga. DR merasa lebih baik jauh berobat ke Bandung daripada di Karawang, "kalo di kampung mah penyakit kayak gini suka dijemberin orang, jadi kita gak banyak cerita, takut orang jember (jijik) ntar sama kita, kan di kampung mah suka dikucilkeun..”. Hal ini hampir mirip dengan hasil penelitian yang menunjukkan bahwa public health messages that raise women's awareness of the sexually transmitted nature of HPV may increase their feelings of stigma and shame if they test positive for the virus (Waller, LAV Marlow, and JWardle, 2007). Karena dianggap memiliki penyakit yang menjijikkan, maka mereka tidak mau diketahui orang banyak sebagai penyandang kanker serviks. Sebagai akibatnya, subjek penelitian mendapatkan informasi terkait penyakitnya manakala tingkat keparahan kanker serviksnya sudah relatif tinggi yaitu stadium IIB-IIIB. Demikian pula pengalaman WAR dari Cirebon yang merasa sangat kesepian, ketika harus 
menjalani tindakan pengobatan di Bandung dan tinggal di rumah singgah, "Disini sakit ngga ada yang nemenin, kalo di Bandung sendirian". Kesepiannya berlanjut ketika WAR pulang ke Cirebon mendapati anak tunggalnya menolak kehadiran WAR mengunjungi rumahnya, "Mi jangan ke rumah Mi ntar takut nular". Lebih jauh, anak WAR tidak mau membawa anaknya (cucu WAR) ketika menjenguk karena takut ketularan. Demikian pula dengan masalah ekonomi yang sangat terkena dampak dengan adanya serangkaian pemeriksaan dan proses pengobatan yang memakan banyak biaya, "Berobat sampe setahun suami bilang, aduh sakit ga sembuh-sembuh, uangnya udah abis, udah ludes, suami ga mau kesini (Bandung), pusing..."

Informasi terkait kanker serviks sudah seharusnya menjadi kebutuhan bagi perempuan yang memiliki gejalanya walaupun tidak semua perempuan merasa membutuhkannya. Beberapa diantara mereka bahkan tidak ingin mengetahui informasi penyakit berkaitan dengan gejala yang sedang dialaminya. Mereka mengulur waktu untuk mengunjungi pihak medis karena tidak ingin mendengar jenis penyakit yang menurut perkiraannya sangat menakutkan. Penyandang kanker serviks ini mengalami disonansi kognitif, dimana dalam pikirannya ada dua pengetahuan yang saling bertolak belakang (Griffin, 2012), yaitu mengalami gejala yang tidak normal pada bagian vital dari tubuhnya, tapi pengetahuan yang lain mengatakan tidak ada rasa sakit apapun yang dialaminya. Mereka berusaha menghilangkan rasa tidak nyaman karena adanya dua pengetahuan yang berbeda dengan mengingkari (denial) terhadap realitas yang dialaminya dengan meyakinkan dirinya maupun orang lain bahwa semuanya baik-baik saja.

Hampir semua subjek penelitian yang berasal dari luar Bandung tidak langsung mencari informasi terkait gejala awal yang mereka alami seperti menstruasi yang berlangsung lama, perdarahan setelah berhubungan seksual, dan keputihan yang tidak pernah sembuh. Selain takut menerima kenyataan mengetahui diagnosis penyakitnya, mereka juga terkendala masalah biaya, "saya ga punya BPJS..ga punya uang.. saya harus dirawat, dirawat pake apa.. pake uang ga punya..orang ga mampu saya tuh..". Akhirnya informasi tentang kanker serviks diperolehnya juga dari pihak medis, namun dengan kondisi penyakit yang sudah meningkat keparahannya. Informasi yang diperoleh dari pihak medis menjadi satusatunya informasi bagi penyandang kanker yang berasal dari luar Bandung, kecuali DH yang berasal dari Bekasi yang suaminya dosen ITB dan anak-anaknya yang juga berpendidikan tinggi. Melalui suami dan anak anaknya, DH memperoleh banyak informasi terkait kanker serviks, tindakan yang harus dijalaninya, pengobatan yang harus dilakukannya dan pola makan dan jenis makanan yang harus dijaganya. Kebutuhan informasi kanker serviks memang dibutuhkan oleh suami dan anak-anak DS. Mereka mencarinya dari internet dan sumber lainnya seperti buku, majalah dan televisi. Informasi tentang kanker serviks kemudian disampaikannya kepada ibunya (DS) dalam bentuk sudah dicetak untuk memudahkan membacanya. "Saya mendapatkan informasi dari suami dan anak saya. Mereka adalah orangorang yang dapat menjelaskan kepada saya secara ilmiah apa itu kanker dan bagaimana menyembuhkannya". DSjuga mencariinformasi penyakitnya dari dokter lainnya untuk second opinion. YY yang berasal dari Pangandaran walaupun pendidikannya hanya SD, melalui kedua anaknya mendapatkan informasi tentang kanker serviks melalui internet. YY seorang janda dengan dukungan kedua anak lelakinya memutuskan untuk melakukan kemoterapi di Purwokerto dengan pertimbangan jarak yang lebih dekat dibandingkan pergi ke Bandung. YY menuturkan, "Alhamdulillah, di Purwokerto bisa kemo, jadi ibu pilih Purwokerto aja daripada harus ke Bandung, jauh..”. Begitu pula ketika peneliti wawancarai YY yang pada saat itu sedang menurun kesehatannya dan dirawat di ruang rawat inap Puskesmas Parigi, "Alhamdulillah, ibu bisa dirawat di sini, dekat rumah...".

Lain halnya dengan penyandang kanker serviks yang berasal dari kota Bandung. Mereka langsung mendapatkan informasi dari dokter ketika melakukan pemeriksaan rutin $\mathrm{KB}$. Tidak cukup dengan informasi dari seorang dokter, mereka juga mencari second opinion dari dokter yang lain untuk memastikan jenis dan keganasan penyakitnya serta tindakan yang harus dijalaninya. Selain dari dokter, informasi juga diperolehnya dari buku, seperti yang dituturkan oleh AS, "setelah dapet (kanker serviks) akhirnya baca-baca.. informasi 
dibanyakin.." Begitu pula halnya dengan MV, informasi tentang kanker serviks juga diperolehnya dari teman temannya di Australia, teman teman dokter dan perawat di RSHS dan Boromeus karena MV adalah seorang perawat senior pada saat didiagnosis pertama kali 14 tahun yang lalu.

Pencarian informasi kanker serviks bagi kaum perempuan, terutama bagi yang sudah terdiagnosis juga pernah diteliti sebelumnya yang menemukan adanya kesadaran memperoleh informasi bagi para penyandang kanker serviks. Penelitian Rahayu \& Ochoa (2015) menunjukkan bahwa responden memiliki kesadaran moderat pada informasi dasar tentang kanker serviks, terutama tentang pencegahan, anatomi, pengobatan dan pemeriksaan diagnostik umum, tetapi dengan sedikit pengetahuan atau kesadaran parsial pada item yang berkaitan dengan tanda- tanda dan gejala, etiologi dan cara penularan kanker serviks. Kemudian ditunjukkan bahwa pendidikan tidak signifikan berkorelasi dengan tingkat kesadaran terindikasi kanker serviks, pendapatan bulanan keluarga secara signifikan berhubungan dengan tingkat kesadaran. Penelitian ini menyimpulkan bahwa gender dan tingkat pendidikan tidak selalu menentukan tingkat kesadaran seseorang atau pengetahuan tetapi pendapatan keluarga dapat memberikan kontribusi untuk tingkat kesadaran (Rahayu \& Ochoa: 2015). Penelitian dengan metode dan pendekatan yang berbeda bisa jadi memunculkan hasil penelitian yang berbeda, namun ada juga yang saling menguatkan seperti asumsi pendapatan keluarga berkontribusi pada tingkat kesadaran perlunya mengetahui informasi kesehatan yang berkaitan dengan gejala fisik yang dialami.

Informasi merupakan bagian yang sangat penting dalam mengurangi kecemasan dan ketidakpastian pada penderita kanker. Beberapa penelitian terdahulu menyebutkan bahwa terdapat kebutuhan informasi yang berbeda antar penyandang kanker. Perbedaan tersebut dipengaruhi oleh berbagai macam faktor seperti jenis kelamin, tingkat pendidikan, kebudayaan, dan lain-lain. Salah satu contohnya adalah penelitian yang dilakukan oleh Yi dkk yang menemukan bahwa kebudayaan di Cina berperan dalam memengaruhi kebutuhan informasi penyandang kanker. Di Cina, penyandang kanker lebih membutuhkan informasi terkait seberapa besar kemungkinan untuk sembuh, seberapa besar kemungkinan penyakit akan kambuh, dan lain-lain. Sementara itu, di Amerika, penyandang kanker lebih membutuhkan informasi terkait metode atau tata cara penyembuhan penyakit (Yi et al., 2016). Kebutuhan informasi dari penyandang kanker serviks dalam penelitian ini menunjukkan adanya perbedaan yang ditengarai dipengaruhi oleh faktor pendidikan. Beberapa subjek penelitian menunjukkan bahwa dalam mengatasi penyakit yang disandangnya tergantung pada tingkat pendidikan yang dimilikinya. Tingkat pendidikan dengan kejadian kanker serviks terdapat hubungan yang kuat, dimana kanker serviks cenderung lebih banyak terjadi pada wanita yang berpendidikan rendah dibanding wanita berpendidikan tinggi (Damayanti, 2013). Menurut Surbakti dalam Damayanti (2013), pendidikan mempunyai hubungan bermakna dengan kejadian kanker serviks, dengan kata lain penderita kanker serviks yang berpendidikan rendah merupakan faktor yang berisiko yang memengaruhi terjadinya kanker serviks.

Tingkat pendidikan berkaitan erat dengan tingkat literasi kesehatan, seperti pernyataan The National Library of Medicine's (NLM) dan Institute of Medicine (IOM) berikut ini tentang literasi kesehatan "the degree to which an individuals have the capacity to obtain, process and understand basic health information and services needed to make appropriate health decisions" (Ratzan dan Parker dalam NielsenBohlman, 2004). Definisi tersebut sangat menarik karena adanya tambahan "It consists of four components (a) cultural and conceptual knowledge, (b) oral literacy, (c) print literacy, and (d) numeracy. Penyandang kanker serviks di luar Bandung dapat dikategorikan tingkat literasi kesehatannya rendah. Padahal menurut Zarcadoolas dkk (2006), rendahnya tingkat literasi kesehatan berkontribusi terhadap beberapa masalahkesehatan seperti, penggunaan obat-obatan yang tidak semestinya, pelayanan kesehatan yang tidak mencukupi, manajemen yang buruk untuk kondisi-kondisi kronis, tanggapan yang lamban untuk kondisi-kondisi yang kritis, kondisi kesehatan yang kurang baik, rendahnya keyakinan dan penghargaan diri, terkurasnya keuangan individu dan masyarakat dan diskriminasi secara sosial. Dapat dikatakan bahwa penyandang kanker serviks di luar kota Bandung berada pada sebuah kondisi yang 
sangat memprihatinkan.

Penyandang kanker serviks yang berasal dari luar Bandung rata-rata berpendidikan SD dengan pekerjaan pedagang keliling, nelayan dan petani. Penyandang kanker serviks yang berpendidikan rendah cenderung mengabaikan informasi mengenai penyakitnya sedangkan yang berpendidikan lebih tinggi cenderung lebih cepat mengetahui penyakitnya. Namun secara umum hasil penelitian menunjukkan bahwa penyandang kanker serviks membutuhkan informasi terkait penyakitnya, makanan yang diperbolehkan atau yang dilarang, gejala penyakit, jenis pengobatan, dan efek dari penyakit. Temuan ini memperkuat hasil penelitian terdahulu yang menyebutkan bahwa penyandang kanker membutuhkan informasi seputar makanan, pengobatan, tata cara hidup bahagia, bersemangat, dan dukungan psikologis (Kimiafar, Sarbaz, Shahid Sales, Esmaeili, \& Javame Ghazvini, 2016; Rogith et al., 2016).

Jenis informasi yang juga dibutuhkan adalah tingkat keparahan penyakit kanker atau biasa disebut dengan istilah stadium. Stadium merupakan klasifikasi penyakit kanker berdasarkan tingkat keparahan yang diderita oleh penyandang kanker. Tingkat keparahan kanker serviks diklasifikasikan kedalam empat kelompok yaitu stadium satu, dua, tiga, dan empat. Ada perbedaan pendapat terkait apakah penyandang kanker perlu mendapatkan informasi seputar tingkat keparahan penyakit tersebut. Penelitian yang dilakukan oleh Yi menyebutkan bahwa penderita kanker di Cina merasa memerlukan informasi tersebut dalam rangka mengurangi tingkat ketidakpastian. Sementara itu, keluarga berpendapat bahwa pasien tidak membutuhkan informasi tersebut karena akan menimbulkan stres pada pasien (Yi et al., 2016). Subjek penelitian yang berasal dari luar Bandung tidak atau kurang dapat memahami makna dari stadium. Sebagian besar subjek penelitian tidak terlalu memikirkan tentang stadium, seperti yang dituturkan oleh ATK," dokter bilang, ini mah serviks sudah IIB.. kan kita ngelohok bengong, tapi saya mah ga soak, jadi ga ada rasa takut, takut mati lah.. apa lah.." Pernyataan dokter tentang stadium dari kanker serviksnya tidak membuat subjek penelitian menjadi sedih, terpuruk apalagi depresi, mereka menjalani sakitnya dengan sabar. Namun YY dari Pangandaran sudah dapat memahami bahwa stadium satu merupakan keadaan yang masih bisa diselamatkan, sedangkan stadium empat merupakan keadaan dimana pasien memiliki peluang yang kecil untuk diselamatkan. Berikut pernyataan YY "stadium itu mungkin, apa ya. kan ke 1 ke 2. Kalau ke tiga itu udah menjelang ke 4 ngga bisa di apa apain. kayak misalnya Jupe..”. Berbeda dengan penyandang kanker serviks dari kota Bandung yang sangat memaknai arti stadium ini. Mereka sangat menyadari bahwa pengobatan yang ditunda akan menyebabkan kenaikan stadium menjadi lebih tinggi lagi yang dapat berakibat fatal. Oleh karena itu, ketika mereka divonis stadium IA dan IB, mereka tidak membuang waktu untuk segera mengambil tindakan operasi. Informasi lain yang dibutuhkan adalah penyebab kanker serviks, "dokter, kanker serviks itu apa sih ? katanya dari virus. Virus itu apa sih..”? Mereka sering tidak mendapat jawaban langsung dari dokter, tapi dari sesama penyandang kanker yang kebetulan ada di Rumah Sakit.

Informasi seputar makanan merupakan informasi terkait jenis-jenis makanan yang diperbolehkan dan tidak diperbolehkan selama menjalani proses pengobatan. Salah satu informan yaitu DH sudah memiliki informasi yang cukup memadai terkait makanan apa saja yang bisa ia konsumsi, seperti tergambar dalam kutipan wawancara berikut, "dulu setelah dikemo dan disinar, saya tidak diperbolehkan makan makanan yang pedas dan asam-asam... kalau seperti teh botol kan udah divonis ngga boleh, mie instan ngga boleh kata dokter di sana, ikan juga harus dipilih, yang segar, yang berwarna putih kata dokter...". Sedangkan MV mendapati informasi makanan seperti ini, "Setelah terdiagnosis kanker serviks, masakan tidak pernah pake penyedap lagi, tidak pernah minum bergula, pewarna dan pengawet. Tidak makan daging merah, dibanyakin ikan. Brokoli bisa 8-10 kg sekali beli...". WAR penyandang dari Cirebon juga mengatakan bahwa, "kata temen jangan makan pedes, mecin dan asin.. kalo kata dokter ga boleh makan baso, harus bikin sendiri.. saya akhirnya makan tempe tahu aja dan sayuran dan buahnya..”.

Informasi berikutnya yang dibutuhkan oleh penyandang kanker serviks adalah informasi jenis pengobatan. Sebagian besar informan membutuhkan informasi jenis pengobatan seperti kemoterapi, radioterapi, herbal, dan lain-lain. Hal tersebut karena rata-rata informan memiliki tingkat pendidikan yang rendah dan 
belum pernah terpapar informasi seputar kanker serviks. Banyak yang menghindari tindakan pengobatan kemoterapi lalu mencoba herbal, "padahal herbal juga ga bisa bantu, karena proses penyembuhannya juga lama, kejar kejaran sama kanker yang ganas, makanya harus kemo, harus dimatiin kankernya.." begitu penuturan AS yang tidak mempercayai pengobatan herbal. Akibatnya, informan melakukan trial and error dalam menempuh pengobatan. Misalnya, salah satu informan menyebutkan bahwa ia pernah mencoba obat alternatif atau herbal karena menerima masukan dari teman dan tidak memiliki pengetahuan sebelumnya mengenai teknik pengobatan tersebut. Meskipun pada akhirnya teknik pengobatan tersebut dihentikan karena tidak memberikan efek apapun. Seperti yang dikemukakan oleh Carstairs dan Kapur dalam Foster dan Anderson (2005) bahwa "kecenderungan masa kini bagi pasien yang sakit fisik adalah pergi ke dokter modern dahulu, kemudian barulah pergi ke penyembuh tradisional, apabila obat dari dokter tidak segera mempunyai efek". Atau sebaliknya, langsung melakukan pengobatan tradisional sebagai alternatif pilihan karena kesulitan mengakses fasilitas kesehatan yang disediakan oleh pemerintah. Pengobatan alternatif memang dapat menjadi solusi yang tepat karena dianggap lebih murah, mudah dan cepat menyembuhkan. Namun untuk masalah kesehatan yang lebih kompleks, pengobatan alternatif yang tradisional ini merupakan cara penyembuhan yang tidak dapat diandalkan. Seperti yang dikatakan oleh Foster dan Anderson, bahwa sistem pengobatan tradisional atau non Barat secara tepat dimasukkan di bawah kategori pengobatan pendukung psikososial (2005). Artinya bahwa pengobatan tradisional secara efektif hanya dapat mengobati penyakitpenyakit yang disebabkan disfungsi tidak hanya dalam tubuhnya namun juga dengan masyarakat dan lingkungannya.

Kanker serviks memang penyakit yang mematikan, terutama jika sudah menginjak pada stadium lanjut. Oleh karena itu diperlukan informasi yang bersifat preventif untuk pencegahan terdiagnosis kanker serviks, terutama sampai pada stadium lanjut. Informasi yang bersifat preventif adalah informasi pencegahan mulai dari gaya hidup, yaitu tidak bergonta-ganti pasangan, membatasi kehamilan dengan mengikuti program $\mathrm{KB}$, menikah di atas 20 tahun, dan tidak merokok. Hal lain yang harus diperhatikan adalah menjaga kebersihan organ intim, mengganti pembalut kewanitaan sesering mungkin, dan berhatihati menggunakan toilet umum. Informasi tersebut harus sudah menjadi pengetahuan dan perilaku perempuan, khususnya perempuan yang telah menikah. Mereka juga harus mengetahui dan melaksanakan pemeriksaan organ intimnya dengan cara pap smear atau IVA test secara rutin sesuai dengan usianya, yang biasanya berkisar 6 bulan - 3 tahun sekali. Dari pengamatan di lapangan terutama untuk daerah di luar Bandung, sosialisasi kanker serviks sebetulnya secara periodik dilakukan oleh dinas kesehatan di setiap wilayahnya, namun diketahui bahwa animo perempuan dalam menghadiri undangan sosialisasi kanker serviks tidak menggembirakan, terlebih dengan adanya pemeriksaan pap smear atau IVA test. Mereka merasa enggan untuk memeriksakan organ intimnya kepada petugas kesehatan. Oleh karena itu tidak mengherankan jika hampir semua subjek penelitian yang berasal dari luar Bandung belum pernah mendapatkan informasi tentang kanker serviks secara resmi dari petugas kesehatan ataupun dari pihak lain. Seperti yang dituturkan oleh ATK, "baru sekarang denger pap smear .. Pas udah disini (di Bandung) lama. Nggak ngerti kan kita mah orang kampung. Jadi nggak tau...”.

Model pada gambar 1 adalah upaya pemetaan peneliti terkait penyandang kanker serviks di Jawa Barat dengan berbagai masalah yang melingkupinya dalam mendapatkan akses terhadap informasi kesehatan. Akses informasi yang berbeda dilatarbelakangi oleh latar belakang sosial dan fasilitas kesehatan yang berbeda antara penyandang kanker serviks yang berada di kota Bandung, dan penyandang kanker serviks yang berada di luar kota Bandung. Informasi terkait kanker serviks yang diperolehnya dari dokter dan sumber lainnyajuga ditentukan oleh dukungan keluarga, dukungan lingkungan, keterampilannya berkomunikasi, keterlibatannya dalam komunitas dan hubungan sosial yang dimilikinya.

Salah satu teori yang tepat digunakan untuk mengkaji penelitian ini adalah teori tindakan sosial dari Max Weber. Pencarian informasi yang dilakukan oleh penyandang kanker serviks dalam upaya penyembuhan merupakan sebuah tindakan sosial yang dilakukannya untuk 


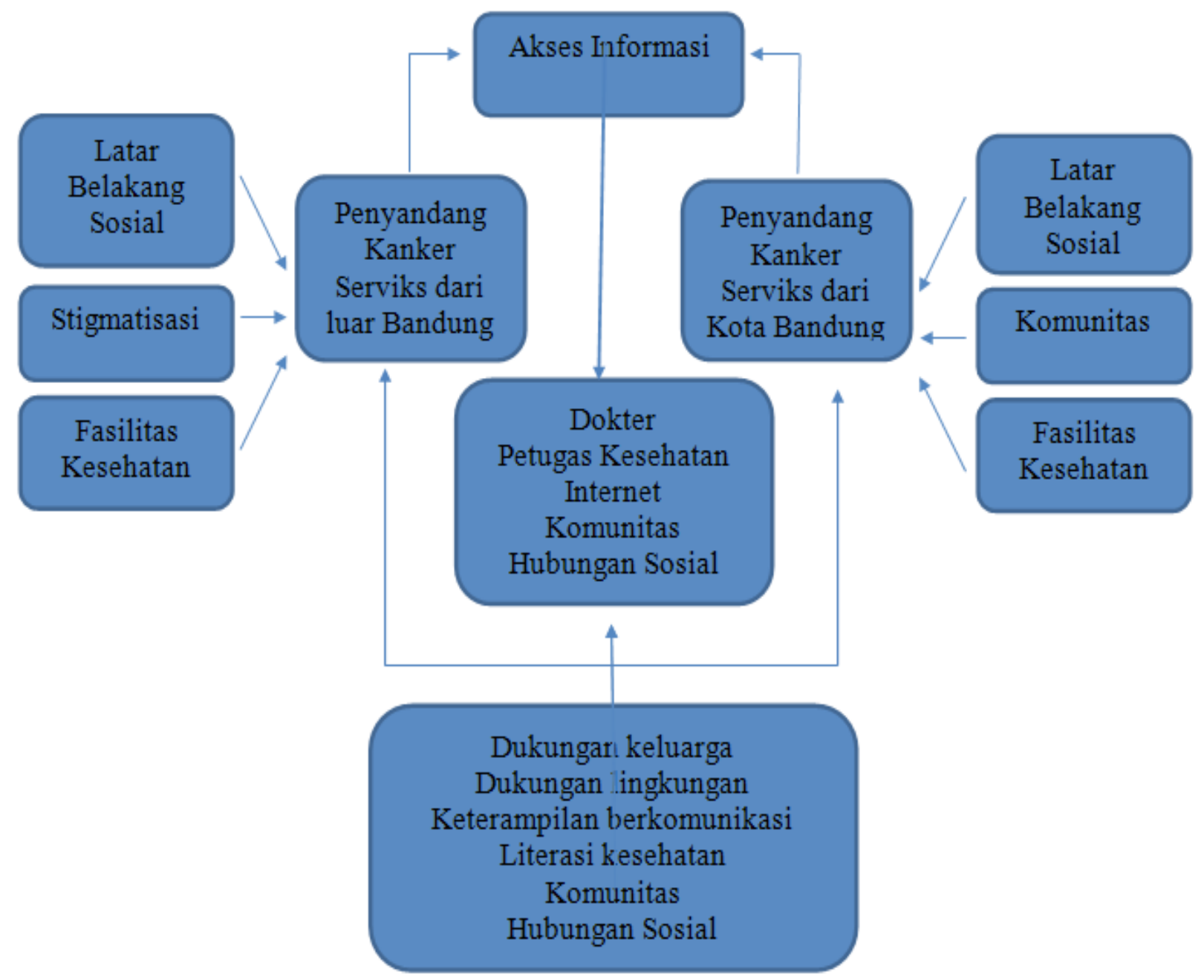

Sumber: Hasil penelitian, 2017

Gambar 1 Model Profil Dan Pola Pencarian Informasi Penyandang Kanker Serviks Dalam Upaya Pengobatannya Di Jawa Barat

memenuhi kebutuhan akan informasi mengenai penyakit yang disandangnya. Para penyandang kanker serviks dapat memutuskan bagaimana mereka harus mencari informasi tentang penyakit yang mereka derita agar mereka dapat memperoleh pengetahuan mengenai apa yang harus mereka lakukan agar mereka bisa menerima dan melakukan pengobatan yang terbaik sebagai upaya penyembuhan. Menurut Max Weber, tindakan sosial ialah perbuatan manusia yang dilakukan untuk memengaruhi individu lain di dalam masyarakat (Ritzer: 2005). Jadi tindakan yang dilakukan oleh informan penelitian ketika pergi ke Rumah Sakit adalah untuk memengaruhi individu lain, terutama pihak medis untuk memberikan pertolongannya dalam upaya menyembuhkan penyakitnya. Begitu pula ketika mereka mencari informasi tentang pola makan yang baik dan benar, maka tindakannya ini berpengaruh kepada pola makan semua anggota keluarganya.

Tindakan setiap penyandang kanker serviks tidak dapat digeneralisir karena setiap individu memiliki latar belakang, lingkungan, dan karakteristik individu yang berbeda pula. Dengan latar belakang sosial yang berbeda, walaupun memiliki kesamaan gejala fisik terkait kanker serviks, maka tindakannya akan berbeda sama sekali yang pada gilirannya berpengaruh pada perilaku orang-orang di sekitarnya, apakah dapat membantu penyembuhan atau bahkan memperparah kondisi kesehatannya. Begitu pula dengan karakteristik individu yang berbeda, yang akan merespons stimuli yang diterimanya dengan berbeda pula. Penyandang kanker serviks dengan karakter pemberani dan 
risk taker akan segera merespons sesuai dengan tindakan yang harus dilakukannya. Mereka tidak akan denial atau mengingkari kenyataan yang harus dihadapinya. Mereka akan sangat pro aktif dan menyegerakan tindakan untuk mengatasi masalahnya, tidak dengan menunda-nunda masalah yang akan berakibat pada semakin parahnya kondisi kesehatannya. Sebaliknya, penyandang kanker serviks yang penakut atau yang menganggap enteng masalah. Mereka akan menganggap gejala awal kanker serviks seperti keputihan yang berlebihan, perdarahan di luar siklus menstruasi, perdarahan setelah berhubungan intim, dan perut yang membesar seperti hal yang biasa, yang akan mereda dengan sendirinya. Mereka akan mempercayai informasi seperti terlalu lelah, menopause, keracunan obat, atau penyakit biasa saja untuk memberi makna terhadap perdarahan. Mereka akan dibawa ke rumah sakit manakala kondisinya sudah parah yang biasanya berada pada stadium IIB atau lebih. Penyandang kanker serviks yang penakut atau menganggap enteng masalah menjadikannya mengalami hambatan untuk mendapatkan informasi sesuai dengan pendapat Harry dan Dewdney dalam Julien (1999: 45) bahwa perempuan secara umum memiliki hambatan dalam mendapatkan informasi yang dibutuhkannya karena tidak mengetahui kebutuhan informasinya, tidak mengetahuidimanamendapatkaninformasiyang dibutuhkannya, tidak mengetahui keberadaan sumber informasi yang dibutuhkannya, tidak menemukan sumber informasi yang sesuai dengan kebutuhan informasinya dan kurangnya keterampilan komunikasi, kepercayaan diri, dan kemampuan.

Weber berpendapat bahwa struktur beberapa masyarakat dapat dibandingkan dan dipahami dengan alasan mengapa warga masyarakat bertindak (Ritzer, 2005). Kejadian historis (masa lalu) yang memengaruhi karakter mereka, dan tindakan para pelakunya yang hidup di masa kini dapat dipahami namun tidak mungkin menggeneralisasi semua masyarakat atau semua struktur sosial. Perilaku masyarakat tidak dapat dipisahkan dari perilaku para pemimpin atau pemerhati masalah yang dihadapi oleh masyarakatnya. Bisa jadi pemerintah masih belum optimal dalam menginformasikan atau menyosialisasikan kanker serviks terhadap masyarakatnya.

Model pencarian informasi yang dilakukan oleh penyandang kanker serviks di Jawa Barat dapat dijelaskan sebagai sebuah peristiwa interaksi simbolik. Penyandang kanker serviks di Jawa Barat, berdasar pada teori ini dianggap sebagai individu yang di dalam dirinya memiliki esensi kebudayaan, berinteraksi di tengah sosial masyarakatnya untuk dapat memperoleh informasi mengenai penyakitnya, dan menghasilkan makna "buah pikiran" yang disepakati secara kolektif untuk dapat memutuskan jenis pengobatan yang harus dilakukan. Para informan yang sebagian besar berpendidikan rendah dengan status sosial menengah ke bawah memiliki kemampuan menggunakan simbol yang relatif terbatas. Mereka kurang memiliki kemampuan untuk mengembangkan interaksinya dengan orang lain terkait penyakit yang disandangnya. Bahasa sebagai alat komunikasi kurang mereka kuasai terlebih untuk istilah-istilah medis yang seringkali terdengar asing sehingga sulit dipahami maknanya. Kemampuan berbahasa yang terbatas memunculkan pikiran yang sederhana berkaitan dengan penyakitnya yang tidak menunjukkan kekhawatirannya dibanding dengan penyandang kanker yang lebih berpendidikan dengan status sosial yang lebih tinggi.

Informan yang berpendidikan rendah ini, kemampuan untuk merefleksikan dirinya yang sakit juga kurang baik, terlihat dari cara menuturkan pengalaman sakit yang sangat luar biasa, namun disampaikan dengan gaya yang biasa saja. Penggunaan simbol bahasa, manusia dapat melakukan hal-hal seperti, memberi nama manusia, mengingat, membuat kategori, merasa, berpikir, berunding, memecahkan masalah, menembus ruang dan waktu, masuk ke dalam diri dan orang lain, menciptakan abstraksi, menciptakan ide-ide baru, dan mengarahkan diri sendiri (Charon, 2007). Kemampuan menggunakan bahasa berkaitan dengan referensi dan pengalaman. Kondisi yang mereka jalani seharusnya terefleksikan sesuai dengan persepsi orang yang diajaknya berkomunikasi. Bagi peneliti, kondisi subjek penelitian yang perutnya membesar atau perdarahan terus menerus dari kedua lubang saluran pembuangan adalah sebuah pengalaman yang sangat menyeramkan. Namun, para informan tidak mengubah gaya bahasa dan bicaranya ketika menuturkan pengalaman yang menyeramkan tersebut. Kemampuan 
mengekspresikan diri terkait pengalaman sakit ini merupakan hambatan yang berasal dari diri penyandang kanker serviks yang merupakan hambatan yang dihadapi pencari informasi pada kegiatan komunikasi interpersonal dengan sumber informasi karena hambatan penyingkapan (disclosure barrier). Hal ini sesuai dengan temuan Mc Kenzie bahwa perempuan seringkali menggambarkan hambatan yang berhubungan dengan pengelakan, penundaan, atau kepura-puraan serta pembelit-belitan. Hal ini seringkali terjadi terutama dalam komunikasi formal antara pencari dan penyedia informasi. Sedangkan berkaitan dengan keengganan penyandang kanker serviks untuk mencari informasi langsung kepada dokter disebabkan karena dokter dianggap tidak ada waktu untuk menjawab pertanyaan pasien. McKenzie (2002) menyatakan bentuk hambatan ini sebagai hambatan yang berasal dari penyedia/ sumber informasi ketika dia tidak berkenan untuk menjawab atau menyajikan jawaban atau informasi atas pertanyaan yang diajukan oleh pencari informasi.

Para informan yang berpendidikan rendah juga kurang memiliki hubungan sosial yang baik dengan masyarakatnya. Terlebih ketika mereka menjadi penyandang kanker serviks yang dianggap penyakit yang menjijikkan atau bahkan menular, sehingga tidak mendapat dukungan dari lingkungannya. Akibat dari respons masyarakat terhadap kondisi para informan ini, maka mereka kemudian mengambil peran sebagai orang sakit yang sudah tidak layak lagi berada di sekitar orang sehat, sehingga membuat mereka memilih tinggal di rumah saja, mengucilkan diri dari lingkungannya.

Lain halnya dengan informan yang berpendidikan tinggi dengan status sosial yang lebih tinggi, mereka justru menuturkan pengalamannya saat didiagnosis dengan membayangkan dirinya meninggal dengan mengenakan gaun yang disukainya dengan foto diri yang sudah dipilihnya. Mereka lebih memiliki kemampuan taking the role of others dibandingkan dengan informan penyandang kanker yang berpendidikan lebih rendah. Dalam hubungan sosialnya dengan masyarakat pun, informan dengan pendidikan tinggi ini lebih dapat mengambil peran sebagai motivator dan pendamping bagi penyandang kanker lainnya, alih-alih menarik diri dari lingkungannya, mereka bahkan terlibat aktif di dalam komunitas seperti Bandung Cancer Society (BCS). Sebagai manusia, para informan penyandang kanker ini adalah makhluk sosial yang melakukan interaksi secara terus menerus dalam hidupnya. Namun interaksinya ada yang berkembang menjadi lebih luas dan ada pula yang bahkan tidak berkembang atau bahkan menguncup semenjak menyandang kanker serviks.

\section{SIMPULAN}

Penyandang kanker serviks di Jawa Barat yang menjadi subjek penelitian yang tinggal di luar kota Bandung sebagian besar terdiri dari perempuan yang berpendidikan rendah, pekerjaannya pedagang, petani nelayan dan ibu rumah tangga, ada yang terstigmatisasi, tanpa fasilitas kesehatan untuk pengobatan kanker serviks dengan terdiagnosis awal pada stadium IIB-IIIB. Sedangkan subjek penelitian yang tinggal di kota Bandung lebih tinggi pendidikan formalnya, pensiunan dan ibu rumah tangga, mendapatkan fasilitas kesehatan yang sangat memadai, terdiagnosis awal pada stadium IA-IB, dan terlibat dalam komunitas kanker. Penyandang kanker serviks dari luar Bandung, menangguhkan pencarian informasi karena denial dan ketiadaan biaya. Informasi yang paling utama berasal dari dokter, baru kemudian dari teman yang mengalami sakit yang sama dan dari saudara. Sedangkan penyandang kanker serviks yang tinggal di Bandung mendapatkan informasi segera dari dokter, internet, buku, komunitas dan jaringan lainnya. Jenis informasi yang dibutuhkan oleh penyandang kanker serviks adalah informasi tentang kanker serviks yang meliputi gejala penyakit, tingkat keparahan penyakit (stadium), penularan dan pengobatannya. Informasi berikutnya yang dibutuhkan adalah informasi tentang gaya hidup dan makanan sehat.

Diperlukan diseminasi informasi pencegahan dan pengobatan kanker serviks secara terus menerus oleh pihak terkait untuk memberi pengetahuan deteksi dini pada kaum perempuan; diperlukan pemberdayaan bidan desa dan atau kader kesehatan untuk dapat lebih menjangkau khususnya perempuan yang mengalami gejala awal kanker serviks untuk segera membantu mengantarkannya ke fasilitas kesehatan terdekat; sebaiknya dibentuk komunitas kanker di setiap daerah sebagai 
tempat berbagi pengalaman dan kemudahan mendapatkan informasi dari sesama penyandang kanker.

\section{DAFTAR PUSTAKA}

Charon, J. M. (2007). Symbolic interactionism, an introduction, an interpretation, an integration. London, Prentice-Hall.Inc.

Damayanti, I. P. (2013), faktor-faktor yang berhubungan dengan kejadian kanker serviks di rsud arifin achmad pekanbaru tahun 2008-2010. Jurnal Kesehatan Komunitas. Vol. 2, No. 2, Mei 2013.

Doktersehat. (2017). Siapa sajakah yang beresiko terkena kanker serviks. Diakses dari http://doktersehat.com/siapa-sajakahyang-beresiko-terkena-kanker-serviks/.

FKUI Jakarta. (2000). Kumpulan karya tulis kebidanan.

Foster \& Anderson. (2005). Antropologi kesehatan, Terjemahan. Jakarta: UI Press.

Griffin, E. (2012), a first look at communication theory, eight edition. Mc Graw Hill Co, NY.

Hadisiwi, P. \& Mulyani, H. S. (2013). Profil penyandang filariasis di kabupaten bandung (studi fenomenologis tentang karakteristik dan status sosial penyandang filariasis di kabupaten bandung). Jurnal Kajian Komunikasi, Vol.1 No.2. Diakses dari http://jurnal.unpad.ac.id/jkk/article/ view/6037/3148.

Kimiafar, K., Sarbaz, M., Sales, S. S., Esmaeili, M., \& Ghazvini, Z. J. (2016). Breast cancer patients' informationneeds and informationseeking behavior in a developing country. The Breast, 28, 156-160. https://doi. org/10.1016/j.breast.2016.05.011.

Loo, J. (2007). Retrieved Maret 19, 2016, from www.jeffloo.com/stuff/dissertation/ infbe 071208.doc.

Nielsen-Bohlman, Lynn, editors. (2004). Health literacy, a prescription to end confusion, institute of medicine. Washington DC: The National Academic Press.

Nuranna, L. (2008). Skrining kanker leher rahim dengan merode inspeksi visual asam asetat (iva). Diakses dari http://buk.depkes.go.id.

Rahayu, D. S. \& Ochoa, M. (2015). Cervical cancer awareness: an information dissemination campaign in indonesia. Jurnal Keperawatan Padjadjaran, 3(1).

Ritzer, G. \& Goodman, J. (2005). Teori sosiologi modern. Terjemahan Alimandan. Jakarta: Prenada Media.

Roach, A. R, M. S., Emily L. B. Lykins, M. S., Celestine G. Gochett, BSN, OCN, CCRP, 1 Emily H. Brechting, M.S., Lili O. Graue, M.S., \& Michael A. Andrykowski. (2009). Differences in cancer information seeking behavior, preferences, and awareness between cancer survivors and healthy. Controls: A National, Population-Based Survey, J Cancer Educ. 2009; 24(1): 7379. [PubMed].

Rogith, D., Yusuf, R. A., Hovick, S. R., Fellman, B. M., Peterson, S. K., BurtonChase, A. M., ... Meric- B e r n s t a m, F. (2016). Patient knowledge and information-seeking about personalized cancer therapy. International Journal of Medical Informatics, 88, 52-57. h t t p s :// doi.org/10.1016/j.ijmedinf.2016.01.005.

Thompson, A. D., Miller, K., \& Parrot. (2003). Handbook of health communication. NJ: Lawrence Erlbaum Associates Publishers.

Waller, LA V Marlow, and J Wardle. (2007). The association between knowledge of HPV and feelings of stigma, shame and anxiety, Sexually Transmited Infection. 2007 Apr; 83(2): 155-159. [PubMed].

Widiawaty, N. (2011), Hubungan tingkat pendidikan formal dan tingkat pengetahuan wanita tentang $\mathrm{k}$ an k e r payudara dengan kejadian kanker payudara di borokulon banyuurip purworejo, Jurnal Komunikasi Kesehatan. Edisi 3, Akbid Purworejo,Vol 2, No 02 (2011).

Yi, T. wu, Deng, Y. tiao, Chen, H. ping, Zhang, J., Liu, J., Huang, B. Yan, Jiang, Y. (2016). The discordance of information needs between cancer patients and their families in China. Patient Education and Counseling.

Zarcadoolas, C., Pleasant, A. F, Greer. D. S. (2006). Advancing health literacy, a ramework for understanding and action, johnwiley \& sons, inc, ca. Information Seeking in the American Public, He a lt h Education \& Behavior, 2016, Vol. 43(4) 461-470. 